\title{
Academic Freedom and Society: Some Critical Questions
}

\author{
Lara Choksey* \\ Institute of Advanced Studies, University of Warwick \\ *Correspondence: L.E.Choksey@warwick.ac.uk
}

\begin{abstract}
A$ review of a recent one-day conference, Academic Freedom and Society, held on June 22017 at the University of Warwick, which sought to pose questions about ideals and practices of academic freedom, historically and in the current moment, across disciplinary and national borders. Speakers discussed the university and human rights practices, Islamophobia and teaching law, 'Decolonise the University', links between funding and research, digital piracy, new sites of knowledge commons, and university managerialism, and the challenges and possibilities these topics pose to the practice of academic freedom. Has the university ever been autonomous from state interests, and what modes of freedom are currently available to academics - already unevenly contingent on social and national identifications - in practice?
\end{abstract}

Keywords: academic freedom; global history; decolonisation; human rights; law; cultural production

Funding: See page 116

Peer review: This article has been subject to a double blind peer review process

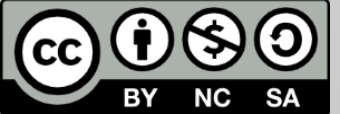

C Copyright: The Authors. This article is issued under the terms of the Creative Commons Attribution NonCommercial Share Alike License, which permits use and redistribution of the work provided that the original author and source are credited, the work is not used for commercial purposes and that any derivative works are made available under the same license terms.
How can the history and philosophy of academic freedom and its representations in culture inform us about current debates about the place and function of the academic in society? This one-day conference sought to pose questions about ideals and practices of academic freedom, historically and in the current moment, across disciplinary and national borders. The three keynote speakers - Bruce Gilbert (Bishop's, Canada), Shaheen Sardar Ali (Warwick), and Robbie Shilliam (QMUL) - provided touchstones for discussions throughout the day, while three panels focused on ideas of the university; property, knowledge and data; and university, commons and state. One of the central questions of the day was not the erosion of academic freedom, but whether it has ever existed in practice; discussions moved from the university constructed as a sacred space for the pursuit of truth, to addressing a priori exclusions that academia has always fostered along lines of race, gender, sexuality and religion, as well as how universities continue to function as laboratories of knowledge and practices in which various kinds of exclusion are both manufactured and reproduced. 
Bruce Gilbert began the conference with a central challenge to the contemporary Western academy: if the Humanities have dismantled the pursuit of 'universal truth' over the two past centuries, then what is the measure of 'good speech' and 'the good'? He outlined three phases of the Western academy: first, the Aristotelian model of higher education, in which church and state acted as benefactors and guardians of the university, and the utility of universities lay, in part, in their ability to help nations promote national interests in the context of the sacred pursuit of a divine truth. Second, with critiques from authors like Nietzsche and Marx on the metaphysical conception of universality - Nietzsche describing truth as 'a mobile army of metaphors, metonyms, and anthropomorphisms' (1873: 3) - the idea of attaining absolute truth began to evaporate. Consequently, the idea of the university as a sacred space designed for truth-seeking, and further, for the defence of academic freedom as such, begins to dissolve. For Gilbert, we find ourselves now in a third phase characterised by the problem of how to defend the university as a site of 'good speech' after the epistemological revolution of post-metaphysical philosophy. The answer, Gilbert suggests, is to give up the dream of sacred universality, towards the ambivalence of human rights, the contradictions and contingencies of living in the world. Drawing on his experiences as an activist in post-colonial land struggles in Brazil, he suggested adopting the human rights tradition for the purpose of collective transformation. For Gilbert, the 'good speech' the university can facilitate consists in the mutual recognition of individual and collective agents in what is an undeniably global village.

Johannes Niederhauser (Warwick) began the panel on Ideas of the University with a talk on the concept of Bildung in the Humboldt university ideal: the idea of self-activity or self-cultivation that also involves breaking even, or making a surplus, of growth and expansion. The telos of this ideal is wholeness and totality, and the role of the state is one only of funding, rather than intervention. Yet, Christopher Ivins (Warwick) argued in his paper, 'Why Have the Universities Stopped Teaching the Meaning of Life?', in practice, universities are prime movers in the twenty-first century knowledge economy. Drawing on Marina Warner's critique of the 'disfiguring of higher education' under new managerialism, Ivins discussed what Warner calls 'the robotic idiom of management' with its emphasis on economic performance which, Warner writes, 'superimpos[es] the imagery of the market on the idea of the university' (2015: 4). As debt-carrying consumers, students become preoccupied with the immediate requirements of assessment, asking questions of 'now', restricted to the present demands rather than free(r) to hold off evaluating their own learning experience in years to come, and to learn instead the limits and structural restrictions of this 
experience; what Ivins calls 'teaching ignorance'. Simon Grimble (Durham) addressed the relative silence of the wider academic community in pushing back against the effects of the 2010 Browne Review. He identified a carrot-stick mentality in contemporary UK universities, particularly among mid-career academics, invariably submerged in balancing the minutiae of administration with research. Against this, Grimble set the call in Stefan Collini's work to escape a 'mission-statement present': the responsibility to make space in the academy for bringing together thinking and feeling, a variety of tones and styles. Contrary to the Humboldt ideal, there is a failure in the current climate to defend the right to extend human capacity, and a need to develop public-mindedness in relation to what is happening.

The second panel, Property, Knowledge, Data, moved more explicitly to issues of research and/as corporate profit, and the fragile relationship between private profit and public knowledge in academic publishing. Hannah Hickman (Sheffield) tackled the topic of uneven access to academic knowledge, despite the utopian promises of digitalising information. Suggesting digital piracy as a way to resist corporate capture, she posed SciHub as an experimental model for abstention from this market, while attentive to the obvious limits of such an approach. What is required, she argued, is a deeper engagement of academic producers with the political economy of their own knowledge dissemination. Felipe Figueroa Zimmermann (Warwick) spoke on 'Academic Freedom, Intellectual Property and the Autonomy of Cultural Production', intervening in this discussion of autonomous/extra-institutional knowledge circulation by asking: how and when did intellectual property become a threat to academic freedom? The vision of a free and open internet in the model of Creative Commons - as espoused and developed by, among others, the programmer and activist Aaron Swartz - has been aggressively resisted by a matrix of corporate and state powers. In this increasingly privatised information economy, he argued, the ideal of general access under the principles of public interest has all but disappeared, and particularly when it comes to the expansion of the research university in the direction of industrial science. As Clémence Pinel $(\mathrm{KCL})$ outlined in the following paper, a spirit of entrepreneurship often motivates researchers in biomedical science laboratories; taking the example of current studies in epigenetics, she explained that research questions are frequently driven by what is considered high impact, attractive for big grants, and will make good headlines in famous science journals.

Shaheen Sardar Ali extended the geography of secular humanist learning in describing her experiences of teaching 'Islamic law' in UK universities. She discussed both the long history of the construction of what is called 
'Islamic law', as well as some of the challenges of teaching it in both and Pakistani and British universities. 'Islamic law', she explained, is a colonial invention, an agglomeration of transcriptions gathered by imperial protoethnographers as they travelled on horseback through the then-far reaches of the British Empire. In one village, they might encounter a particular marriage custom or death ritual; in another, a set of entirely different protocols. The implications of this for colonial knowledge production in the contemporary British university are immense, and for this reason, Ali emphasised that it is important to teach law in context, critically and robustly, rather than becoming an apologist for religion. Understanding Islamic law as the historical narrative made up of multiple sources - pre-colonial, tribal, colonial and post-colonial - helps students to understand the contingency and strategic deployment of both Islamist and Islamophobic rhetoric in contemporary global geopolitics.

The final panel, University, Commons, State, explored connections and conflicts between the university, civil society and state power. Richard Elliott (Edinburgh) questioned the efficacy of what he termed 'studentled changes' to core curricula in the wake of the recent 'Decolonise the University' and 'Rhodes Must Fall' campaigns, raising concerns around what he saw as the politicisation of university curricula; the ensuing debate in the question session echoed an wider set of concerns about a general amnesia in European national histories regarding European imperialism, and the importance of such campaigns in uncovering colonial legacies embedded in the functioning of modern universities. Mike Finn (Warwick), speaking on 'The Question of the State', challenged the notion that universities are (or should be) separate from the political sphere. He argued that while it may seem that 'things just happen' in administration meetings and department decision-making, the constant pace of reform in neoliberal universities means that British higher education has been imbricated in political crises for a long time. For him, state steering has led to an atmosphere in which a work-force of individualised academics willingly engages in its own subordination. Far from the university remaining at a safe distance from state interference, academic freedom is by definition a political value, whose protection demands robust and long-term public defence. Rather than confining critique to abstractions in seminar rooms, Finn proposed working towards the critical university as a lived reality, rather than participating in a culture of self-censorship.

Robbie Shilliam ended the day with his keynote address on 'How Black Deficit Entered the British Academy'. Some of the questions raised in the discussion of the importance of 'Decolonise the University' and 'Rhodes Must Fall' in decolonial practices were explicitly returned to, as Shilliam worked his discussion of the current BME attainment gap in UK Higher 
Education into the argument that the British academy not only reflects but also reproduces racialised social exclusion, a laboratory for cultivating a mythology of Black cognitive deficiency, rather than an instrument of social mobility. Structuring his discussion around three historical moments - 'mute abolitionism', colonial development and post-war race relations - Shilliam charted the rise of social anthropology as a discipline to aid urbanisation in both the UK and British-occupied Africa by constructing a mythological 'black people'. Post-war race relations in the U.K. can be viewed, he argued, as a surrogate to the colony-metropole equivalence under colonial development of rural agricultural land to urban centres of production. This history is one of the cultivation of dependency; in the contemporary British university, this emerges as Black aspiration dependent on white acceptance. Shilliam ended his talk by asking what might be required to change the social reproduction of these colonial dispositions. We need, he suggested, to look both within - to what has been left unchanged in the university, and outwards - to community-based institutions, and Black scholarship outside the academy.

One of the original aims of the conference was to draw together different disciplinary approaches to questions of academic freedom in universities; all the papers of the day carried a common thread of scepticism about the future of higher education, and a sense of urgency about the role of the academic in confronting various - often seemingly benign - forms of corporate and state regulation. This outward resistance should be combined by looking inward, placing a spotlight on forms of teaching and learning that either ignore or contribute to the fossilisation of unacknowledged inequities of race, gender, class and sexuality as they play out in classrooms, lecture halls, and across university campuses. The university has not so much provided a sanctuary from the violence of modernity, as it has cultivated and housed its epistemological conditions. The crisis of neo-liberal managerialism can be understood, then, as only the latest manifestation of social and political constraints which, in practice, the university has always functioned within. If academic freedom remains an ideal for modern universities, however unattainable or impossible, then it is both critical to cultivate a better historical understanding of the fragile and narrow foundations on which such freedom has been based, and also to open up this ideal to opportunities for free and public learning. 


\section{Acknowledgements}

The organisers would like to thank the Centre for Research in Philosophy, Literature, and the Arts (CRPLA), Global Research Priorities (Warwick), and Warwick Library's Postgraduate Community Engagement for their financial support of this event. Thanks also to Eileen John and Sarah Taylor for all their help with organisation. Thank you to all the participants - speakers, chairs and audience - for sharing perspectives and research on this multifaceted and necessarily trans-disciplinary topic.

\section{References}

Nietzsche, F. (1873), 'On Truth and Lies in an Extra-Moral Sense”. Trans. Walter Kaufmann, https://ipcatholic.edu/NCUpdf/Nietzsche.pdf, accessed 14 August 2017

Warner, M. (2015), 'Learning My Lesson', London Review of Books 37 (6), https://www.Irb.co.uk/v37/n06/marina-warner/learning-my-lesson, accessed 14 August 2017

To cite this article:

Choksey, L. (2017). Academic Freedom and Society: Some Critical Questions. Exchanges: the Warwick Research Journal, 5(1), 111-116. Retrieved from: http://exchanges.warwick.ac.uk/index.php/exchanges/article/view/220 